\title{
Influence of Land Configurations and Nutrient Levels on Growth, Yield and Economics of Bt Cotton
}

\author{
V. Ambika ${ }^{1}$, G.S. Yadahalli ${ }^{1}$, B.M. Chittapur ${ }^{1}$, Shamrao Kulkarni ${ }^{1}$, \\ Vidyavathi G. Yadahalli ${ }^{2}$ and Siddu Malakannavar ${ }^{2}$ \\ ${ }^{1}$ Department of Agronomy, College of Agriculture, University of Agricultural Sciences, \\ Raichur-584104, Karnataka, India \\ ${ }^{2}$ Department of Soil Science and Agricultural Chemistry, College of Agriculture, University of \\ Agricultural Sciences, Raichur-584104, Karnataka, India \\ *Corresponding author
}

\section{A B S T R A C T}

\begin{tabular}{|l|}
\hline Ke y w o r d s \\
Nutrient levels, Bt \\
cotton, Land \\
configurations, \\
Ridges and furrows, \\
Broad bed and \\
furrows and flat \\
bed.
\end{tabular}

\section{Keywords}

Nutrient levels, B cotton, Land configurations, Broad bed and furrows and flat bed.

Accepted:

Available Online

10 December 2017
A Field experiment was conducted at Main agriculture research station, University of Agricultural Sciences, Raichur, Karnatka on deep black soil during kharif 2016 to study the yield maximization through in-situ moisture conservation practices in conjunction with nutrient levels in $b t$ cotton. The results of this experiment revealed that there was significant difference in growth and yield attributing parameters with different land configurations and nutrient levels. Ridges and furrows recorded significantly higher leaf area $\left(74.46 \mathrm{dm}^{2}\right.$ plant $\left.{ }^{-1}\right)$, total dry matter production $\left(374.55 \mathrm{~g}\right.$ plant $\left.{ }^{-1}\right)$, seed cotton yield $\left(2403 \mathrm{~kg} \mathrm{ha}^{-1}\right)$ and harvest index (0.35) over flatbed $\left(71.51 \mathrm{dm}^{2}\right.$ plant $^{-1}, 342.76 \mathrm{~g}$ plant $^{-1}, 1743 \mathrm{~kg} \mathrm{ha}^{-1}$ and 0.27 , respectively). Among the nutrient levels application of 90:45:45 NPK kg ha ${ }^{-1}$ (50\% $\mathrm{N}$ through organic) was recorded significantly higher leaf area $\left(74.06 \mathrm{dm}^{2}\right.$ plant $\left.^{-1}\right)$, total dry matter production $\left(369.85 \mathrm{~g} \mathrm{plant}^{-1}\right)$, seed cotton yield (2308 $\mathrm{kg} \mathrm{ha}{ }^{-1}$ ) and harvest index (0.33) over other treatments. Among the interactions significantly higher leaf area $\left(77.19 \mathrm{dm}^{2}\right.$ plant $\left.{ }^{-1}\right)$, total dry matter production $(390.57 \mathrm{~g}$ plant $\left.^{-1}\right)$ and seed cotton yield $\left(2834 \mathrm{~kg} \mathrm{ha}^{-1}\right)$ was recorded in ridges and furrows with application of $90: 45: 45 \mathrm{NPK} \mathrm{kg} \mathrm{ha}{ }^{-1}(50 \% \mathrm{~N}$ through organic) as compared to other treatment combinations.

\section{Introduction}

Cotton (Gossypium spp.), the king of fibre and popularly known as the white gold, enjoys a predominant position among cash crops in India and world as well. The diversity of cotton cultivars and cotton agroclimatic zones in India are considerably larger when compared to other major cotton growing countries in the world. In India, cotton is grown under diverse agro-climatic conditions and contributes nearly 65 per cent of total raw material needs of textile industry.
In India, cotton was cultivated in an area of $11.88 \mathrm{~m}$ ha with a production of 35.2 million bales of seed cotton during 2015-16.

Average productivity of cotton in India is 504 $\mathrm{kg}$ lint $\mathrm{kg} \mathrm{ha}^{-1}$, which is lower when compared to the world average of $725 \mathrm{~kg}$ lint $\mathrm{ha}^{-1}$. Cotton is grown in $7.8 \mathrm{~m}$ ha in 296 districts of which $5.1 \mathrm{~m}$ ha is rainfed in sixteen states of the country and about 85 per cent of the rainfed cotton is grown in 30 districts $(4.1 \mathrm{~m}$ 
ha). Karnataka ranks the fifth in area with 6.12 lakh ha and the fourth in production with 20 lakh bales of lint and fifth in productivity with an average lint productivity of $556 \mathrm{~kg}$ per ha (Anon., 2015-16).

Rainfed regions are not only thirsty; but also, hungry. These soils have low fertile and multi-nutrient deficient so, in rainfed regions need to enhance the soil fertility through proper nutrient management along with moisture conservation.

\section{Materials and Methods}

A Field experiment was conducted during the Kharif 2016 at Main agriculture research station, University of Agricultural Sciences, Raichur, Karnatka situated on the latitude of $16^{0} 12^{1} \mathrm{~N}$ latitude, $77^{0} 20^{1} \mathrm{E}$ longitude with an elevation of 389 meters above mean sea level and is located in North Eastern Dry Zone of Karnataka. The experiment was laid out in split plot design with three main plot and four sub plot. The studies included three in-situ moisture conservation practices $\left(\mathrm{M}_{1}\right.$ : Broad bed and furrows, $\mathrm{M}_{2}$ : ridges and furrows and $\mathrm{M}_{3}$ : flatbed) and four nutrient levels $\left(\mathrm{S}_{1}\right.$ : 60:30:30 NPK kg ha ${ }^{-1}, S_{2}: 90: 45: 45$ NPK kg $\mathrm{ha}^{-1}, \mathrm{~S}_{3}:$ 60:30:30 NPK kg ha ${ }^{-1}(50 \% \mathrm{~N}$ through organic), $\mathrm{S}_{4}: 90: 45: 45$ NPK $\mathrm{kg} \mathrm{ha}^{-1}$ (50\% $\mathrm{N}$ through organic). KCH14K59 BG-II (Jaadoo) variety was selected for study. The soil of the experimental site was deep black and clay in texture with the available nitrogen (192 $\mathrm{kg} \mathrm{ha}^{-1}$ ), phosphorus (30.20 kg ha-1), potassium (207.42 $\left.\mathrm{kg} \mathrm{ha}^{-1}\right)$, organic carbon content $(0.50 \%)$. Sowing was done by dibbling on $20^{\text {th }}$ July, 2016.

All agronomical practices were followed during investigation period and meteorological week wise weather parameters also observed. The net plot wise yield was recorded and subjected to statistical analysis of Panse and Sukhatme (1967).

\section{Results and Discussion}

\section{Effect of land configuration}

The growth and yield parameters are significantly influenced due to different land configuration techniques (Table 1). Leaf area is an important parameter which indicates the photosynthetic surface area and leaf area index which directly indicate interception of solar radiation by the canopy which ultimately influences the photosynthesis and yield of the crop. Leaf area $\left(74.46 \mathrm{dm}^{2}\right.$ plant $\left.^{-1}\right)$, leaf area index (1.38) and total dry matter production (374.55 $\left.\mathrm{g}_{\text {plant }}{ }^{-1}\right)$ had recorded significantly higher in ridges and furrows. Leaf area $\left(72.75 \mathrm{dm}^{2}\right.$ plant $\left.^{-1}\right)$ and leaf area index (1.35) was found on par with broad bed and furrows. Flatbed exerted lower leaf area $\left(67.46 \mathrm{dm}^{2}\right.$ plant $\left.^{-1}\right)$, leaf area index (1.25) and total dry matter production (342.76 g plant $\left.{ }^{-1}\right)$. Seed cotton yield (2403 kg ha ${ }^{-1}$ ) was recorded significantly higher in ridges and furrows followed by broad bed and furrows $\left(2222 \mathrm{~kg} \mathrm{ha}^{-1}\right)$ and lower was observed in flatbed $\left(1743 \mathrm{~kg} \mathrm{ha}^{-1}\right)$. Land configuration, a mechanical measure of insitu moisture conservation in the soil profile reservoir, plays an important role in conservation of maximum possible rainwater in the soil, so availability of more moisture for longer time boost the yield of cotton. These results are in conformity with findings of Pendke et al., (2001), Hulihalli and Patil (2004), Arora and Bhatt (2012).

Harvest index and seed index was significantly higher in ridges and furrows (0.35 and 10.12, respectively) and it was on par with the broad bed and furrow ( 0.33 and 9.86, respectively). Lower harvest index and seed index was noticed with flatbed $(0.27$ and 8.39, respectively). Harvest index is an indication of the translocation efficiency of plants and per cent of dry matter being utilized for production of economic yield and 
seed index indicates weight of seeds so, ridges and furrow efficiently utilized drymatter for production of seed cotton yield. These results are orthodox with findings of Narkhede et al., (2015). Numerically the significantly higher gross monetary return (Rs. 129740), net monetary returns (Rs. 88082 ) and benefit cost ratio (3.10) was obtained under ridges and furrows followed by broad bed and furrows (Rs. 119979, Rs. 78321 and 2.88, respectively) and flatbed (Rs. 94140, Rs. 54983 and 2.41, respectively). Similar findings were reported earlier by Maninder et al., (2007), Hosmath et al., (2004) and Rannavare et al., (2006).

\section{Effect of nutrient levels}

In the present study, leaf area $\left(74.06 \mathrm{dm}^{2}\right.$ plant $\left.^{-1}\right)$, leaf area index (1.37) and total dry matter production (369.85 $\mathrm{g}$ plant $\left.^{-1}\right)$ was increased significantly with application of 90:45:45 NPK kg ha ${ }^{-1}$ (50\% $\mathrm{N}$ through organic) and was found on par with application of 90:45:45 NPK kg ha- ${ }^{-1}$ (73.17 $\mathrm{dm}^{2}$ plant $^{-1}, \quad 1.35$ and $363.72 \mathrm{~g}$ plant $^{-1}$, respectively).

With application of 60:30:30 NPK kg ha-1 had exerted lower leaf area $\left(68.97 \mathrm{dm}^{2}\right.$ plant $\left.^{-1}\right)$, leaf area index (1.28) and total dry matter production $\left(347.16 \mathrm{~g} \mathrm{plant}^{-1}\right)$. These results are in line with the findings of Hosmath et al., (2004) and Rannavare et al., (2006). Photosynthetic capacity of plant depends upon the dry matter accumulation in leaves, which in turn reflects in leaf area and leaf area index. These growth parameters enabled the plant to trap higher quantum of radiant energy due to higher leaf surface area to convert in to chemical energy.

Nutrients with different levels significantly influenced the yield attributes. Significantly higher seed cotton yield $\left(2308 \mathrm{~kg} \mathrm{ha}^{-1}\right)$, seed index $(9.95 \mathrm{~g})$ and harvest index (0.33) had recorded with application of 90:45:45 NPK $\mathrm{kg} \mathrm{ha}^{-1}(50 \% \mathrm{~N}$ through organic) and lower was observed with application of 60:30:30 NPK kg ha ${ }^{-1}$ (1937 kg ha ${ }^{-1}, 9.19 \mathrm{~g}$ and 0.30, respectively). These results are conformity with the findings of Babalad and Itnal (2004), Hosmath et al., (2004), Chadrashekar et al., (2004) and Satyanarayana rao and Setty (2007). The positive effects of organic manures on yield and its attributes of cotton could be attributed to the fact that after proper decomposition and mineralization, the organic manures were instrumental in supplying available nutrients directly to the plants and also these sources had solubilising effect on fixed form of nutrients in soil (Sinha et al., 1981). Supply of nutrients through organic and inorganic might have increased the protoplasmic constituents and accelerated the process of cell division and elongation. This in turn might have increased the values of growth and yield contributing attributes, which is reflected in seed cotton yield (Table 2).

Among different nutrient levels gross and net return was significantly higher in the treatment with application of 90:45:45 NPK $\mathrm{kg} \mathrm{ha}^{-1}(50 \% \mathrm{~N}$ through organic) $(\square 124658$ and $104577 \mathrm{ha}^{-1}$, respectively) while lower return was recorded with application of 60:30:30 NPK kg ha ${ }^{-1}$ ( $\square 104577$ and 66640 $\mathrm{ha}^{-1}$, respectively).

Significantly higher benefit cost ratio (2.91) was recorded with application of 90:45:45 NPK kg ha ${ }^{-1}$ and was found on par with application of 90:45:45 NPK kg ha ${ }^{-1}(50 \% \mathrm{~N}$ through organic) (2.79) and lower was noticed with application of 60:30:30 NPK kg ha ${ }^{-1}$ (50\% $\mathrm{N}$ through organic) (2.74).

\section{Effect of land configuration and nutrient levels}

The treatment combinations differed significantly with varied land configurations and nutrient levels. 
Table.1 Growth parameters of $B t$ cotton as influenced by in-situ moisture conservation practices and nutrient levels

\begin{tabular}{|c|c|c|c|c|c|c|c|c|c|c|c|c|}
\hline \multirow{3}{*}{ Treatment } & \multicolumn{12}{|c|}{ Growth parameters } \\
\hline & \multicolumn{4}{|c|}{$\begin{array}{l}\text { Total dry matter production } \\
\qquad\left(\text { g plant }^{-1}\right)\end{array}$} & \multicolumn{4}{|c|}{$\begin{array}{l}\text { Leaf area per plant } \\
\qquad\left(\mathrm{dm}^{2} \text { plant }^{-1}\right)\end{array}$} & \multicolumn{4}{|c|}{ Leaf area index } \\
\hline & \multicolumn{12}{|c|}{ Main plot } \\
\hline Sub plot & $\mathbf{M}_{1}$ & $\mathbf{M}_{2}$ & $\mathbf{M}_{3}$ & Mean & $\mathbf{M}_{1}$ & $\mathbf{M}_{2}$ & $\mathbf{M}_{3}$ & Mean & $\mathbf{M}_{1}$ & $\mathbf{M}_{2}$ & $\mathbf{M}_{3}$ & Mean \\
\hline $\mathrm{S}_{1}$ & 350.08 & 354.01 & 337.38 & 347.16 & 71.56 & 72.38 & 62.97 & 68.97 & 1.33 & 1.34 & 1.17 & 1.28 \\
\hline $\mathrm{S}_{2}$ & 362.77 & 383.89 & 344.51 & 363.72 & 73.29 & 74.89 & 71.32 & 73.17 & 1.36 & 1.39 & 1.32 & 1.35 \\
\hline $\mathrm{S}_{3}$ & 357.84 & 369.74 & 343.18 & 356.92 & 72.67 & 73.38 & 64.06 & 70.04 & 1.35 & 1.36 & 1.19 & 1.30 \\
\hline $\mathrm{S}_{4}$ & 373.00 & 390.57 & 345.96 & 369.85 & 73.47 & 77.19 & 71.51 & 74.06 & 1.36 & 1.43 & 1.32 & 1.37 \\
\hline Mean & 360.92 & 374.55 & 342.76 & & 72.75 & 74.46 & 67.46 & & 1.35 & 1.38 & 1.25 & \\
\hline Source of variance & \multicolumn{2}{|c|}{ S. Em. \pm} & \multicolumn{2}{|c|}{ C.D. at $5 \%$} & \multicolumn{2}{|c|}{ S. Em. \pm} & \multicolumn{2}{|c|}{ C.D. at $5 \%$} & \multicolumn{2}{|c|}{ S. Em. \pm} & \multicolumn{2}{|c|}{ C.D. at $5 \%$} \\
\hline $\mathrm{M}$ & \multicolumn{2}{|c|}{0.63} & \multicolumn{2}{|c|}{2.47} & \multicolumn{2}{|c|}{0.83} & \multicolumn{2}{|c|}{3.25} & \multicolumn{2}{|c|}{0.02} & \multicolumn{2}{|c|}{0.06} \\
\hline$S$ & \multicolumn{2}{|c|}{1.54} & \multicolumn{2}{|c|}{4.57} & \multicolumn{2}{|c|}{0.71} & \multicolumn{2}{|c|}{2.11} & \multicolumn{2}{|c|}{0.01} & \multicolumn{2}{|c|}{0.04} \\
\hline $\mathrm{S}$ at same level of $\mathrm{M}$ & \multicolumn{2}{|c|}{2.66} & \multicolumn{2}{|c|}{7.92} & \multicolumn{2}{|c|}{1.23} & \multicolumn{2}{|c|}{3.66} & \multicolumn{2}{|c|}{0.02} & \multicolumn{2}{|c|}{0.07} \\
\hline $\begin{array}{c}\text { M at same or different level of } \\
\qquad S\end{array}$ & \multicolumn{2}{|c|}{2.39} & \multicolumn{2}{|c|}{7.10} & \multicolumn{2}{|c|}{1.35} & \multicolumn{2}{|c|}{4.01} & \multicolumn{2}{|c|}{0.03} & \multicolumn{2}{|c|}{0.07} \\
\hline
\end{tabular}

Note: NS - Not significant DAS: Days after sowing

Main plots: In-situ moisture conservation practices (M) $\mathrm{M}_{1}$ : Broad bed and furrows (BBF)

$\mathrm{M}_{2}$ : Ridges and furrows $(\mathrm{R} \& \mathrm{~F})$

$\mathrm{M}_{3}$ : Flatbed
Sub plots: Nutrient management (S)

$\mathrm{S}_{1}: 60: 30: 30 \mathrm{NPK} \mathrm{kg} \mathrm{ha}$
$\mathrm{S}_{2}: 90: 45: 45 \mathrm{NPK} \mathrm{kg} \mathrm{ha}$
$\mathrm{S}_{3}: 60: 30: 30 \mathrm{NPK} \mathrm{kg} \mathrm{ha}$
$\mathrm{S}_{4}: 90: 45: 45 \mathrm{NPK} \mathrm{kg} \mathrm{ha}^{-1}(50 \% \mathrm{~N}$ through organic) 
Table.2 Yield parameters of Bt cotton as influenced by in-situ moisture conservation practices and nutrient levels

\begin{tabular}{|c|c|c|c|c|c|c|c|c|c|c|c|c|}
\hline \multirow{3}{*}{ Treatment } & \multicolumn{12}{|c|}{ Yield parameters } \\
\hline & \multicolumn{4}{|c|}{ Seed cotton yield $\left(\mathrm{kg} \mathrm{ha}^{-1}\right)$} & \multicolumn{4}{|c|}{ Harvest index } & \multicolumn{4}{|c|}{ Seed index $(\mathrm{g})$} \\
\hline & \multicolumn{12}{|c|}{ Main plot } \\
\hline Sub plot & $\mathbf{M}_{1}$ & $\mathbf{M}_{2}$ & $\mathbf{M}_{3}$ & Mean & $\mathbf{M}_{1}$ & $\mathbf{M}_{2}$ & $\mathbf{M}_{3}$ & Mean & $\mathbf{M}_{1}$ & $\mathbf{M}_{2}$ & $\mathbf{M}_{3}$ & Mean \\
\hline $\mathrm{S}_{1}$ & 2046 & 2070 & 1694 & 1937 & 0.32 & 0.32 & 0.27 & 0.30 & 9.77 & 9.79 & 8.00 & 9.19 \\
\hline $\mathrm{S}_{2}$ & 2287 & 2395 & 1763 & 2148 & 0.34 & 0.34 & 0.28 & 0.32 & 9.84 & 10.19 & 8.43 & 9.49 \\
\hline $\mathrm{S}_{3}$ & 2230 & 2312 & 1750 & 2097 & 0.34 & 0.34 & 0.28 & 0.32 & 9.81 & 9.99 & 7.80 & 9.20 \\
\hline $\mathrm{S}_{4}$ & 2325 & 2834 & 1767 & 2308 & 0.34 & 0.39 & 0.28 & 0.33 & 10.02 & 10.51 & 9.33 & 9.95 \\
\hline Mean & 2222 & 2403 & 1743 & & 0.33 & 0.35 & 0.27 & & 9.86 & 10.12 & 8.39 & \\
\hline Source of variance & \multicolumn{2}{|c|}{ S.Em \pm} & \multicolumn{2}{|c|}{ C.D. at $5 \%$} & \multicolumn{2}{|c|}{ S.Em \pm} & \multicolumn{2}{|c|}{ C.D. at $5 \%$} & \multicolumn{2}{|c|}{ S. Em.土 } & \multicolumn{2}{|c|}{ C.D. at $5 \%$} \\
\hline M & \multicolumn{2}{|c|}{39.43} & \multicolumn{2}{|c|}{154.9} & \multicolumn{2}{|c|}{0.01} & \multicolumn{2}{|c|}{0.02} & \multicolumn{2}{|c|}{0.19} & \multicolumn{2}{|c|}{0.75} \\
\hline$S$ & \multicolumn{2}{|c|}{53.78} & \multicolumn{2}{|c|}{159.8} & \multicolumn{2}{|c|}{0.01} & \multicolumn{2}{|c|}{0.02} & \multicolumn{2}{|c|}{0.19} & \multicolumn{2}{|c|}{0.58} \\
\hline $\mathrm{S}$ at same level of $\mathrm{M}$ & \multicolumn{2}{|c|}{93.16} & \multicolumn{2}{|c|}{276.8} & \multicolumn{2}{|c|}{0.01} & \multicolumn{2}{|c|}{ NS } & \multicolumn{2}{|c|}{0.34} & \multicolumn{2}{|c|}{ NS } \\
\hline $\begin{array}{c}\mathrm{M} \text { at same or different level of } \\
\mathrm{S}\end{array}$ & \multicolumn{2}{|c|}{89.80} & \multicolumn{2}{|c|}{266.8} & \multicolumn{2}{|c|}{0.01} & \multicolumn{2}{|c|}{ NS } & \multicolumn{2}{|c|}{0.35} & \multicolumn{2}{|c|}{ NS } \\
\hline
\end{tabular}

\section{Note: NS - Not significant}

Main plots: In-situ moisture conservation practices (M)

$\mathrm{M}_{1}$ : Broad bed and furrows (BBF)

$\mathrm{M}_{2}$ : Ridges and furrows $(\mathrm{R} \& \mathrm{~F})$

$\mathrm{M}_{3}$ : Flatbed
Sub plots: Nutrient management $(S)$
$\mathrm{S}_{1}: 60: 30: 30 \mathrm{NPK} \mathrm{kg} \mathrm{ha}^{-1}$
$\mathrm{S}_{2}: 90: 45: 45 \mathrm{NPK} \mathrm{kg} \mathrm{ha}^{-1}$
$\mathrm{S}_{3}: 60: 30: 30 \mathrm{NPK} \mathrm{kg} \mathrm{ha}^{-1}$ (50\% $\mathrm{N}$ through organic)
$\mathrm{S}_{4}: 90: 45: 45 \mathrm{NPK} \mathrm{kg} \mathrm{ha}^{-1}(50 \% \mathrm{~N}$ through organic) 
Table.3 Economics of $B t$ cotton as influenced by in-situ moisture conservation practices and nutrient levels

\begin{tabular}{|c|c|c|c|c|c|c|c|c|c|c|c|c|}
\hline \multirow{3}{*}{ Treatment } & \multicolumn{12}{|c|}{ Economics } \\
\hline & \multicolumn{4}{|c|}{ Gross returns (Rs. ha $\left.{ }^{-1}\right)$} & \multicolumn{4}{|c|}{ Net returns (Rs. ha $\left.{ }^{-1}\right)$} & \multicolumn{4}{|c|}{$B: C$ ratio } \\
\hline & \multicolumn{12}{|c|}{ Main plot } \\
\hline Sub plot & $\mathbf{M}_{1}$ & $\mathbf{M}_{2}$ & $\mathbf{M}_{3}$ & Mean & $\mathbf{M}_{1}$ & $\mathbf{M}_{2}$ & $\mathbf{M}_{3}$ & Mean & $\mathbf{M}_{1}$ & $\mathbf{M}_{2}$ & $\mathbf{M}_{3}$ & Mean \\
\hline $\mathrm{S}_{1}$ & 110472 & 111780 & 91478 & 104577 & 71702 & 73010 & 55208 & 66640 & 2.85 & 2.88 & 2.52 & 2.75 \\
\hline $\mathrm{S}_{2}$ & 123472 & 129303 & 95184 & 115986 & 82985 & 88816 & 57197 & 76333 & 3.05 & 3.19 & 2.50 & 2.91 \\
\hline $\mathrm{S}_{3}$ & 120416 & 124859 & 94500 & 113259 & 78386 & 82829 & 54970 & 72062 & 2.87 & 2.97 & 2.39 & 2.74 \\
\hline $\mathrm{S}_{4}$ & 125555 & 153018 & 95400 & 124658 & 80211 & 107674 & 52556 & 80147 & 2.77 & 3.37 & 2.23 & 2.79 \\
\hline Mean & 119979 & 129740 & 94140 & & 78321 & 88082 & 54983 & & 2.88 & 3.10 & 2.41 & \\
\hline Source of variance & \multicolumn{2}{|c|}{ S. Em. \pm} & \multicolumn{2}{|c|}{ C.D. at $5 \%$} & \multicolumn{2}{|c|}{ S. Em.土 } & \multicolumn{2}{|c|}{ C.D. at 5\% } & \multicolumn{2}{|c|}{ S. Em.土 } & \multicolumn{2}{|c|}{ C.D. at 5\% } \\
\hline M & \multicolumn{2}{|c|}{2129} & \multicolumn{2}{|c|}{8361} & \multicolumn{2}{|c|}{2129} & \multicolumn{2}{|c|}{8361} & \multicolumn{2}{|c|}{0.11} & \multicolumn{2}{|c|}{0.43} \\
\hline$S$ & \multicolumn{2}{|c|}{2904} & \multicolumn{2}{|c|}{8629} & \multicolumn{2}{|c|}{2904} & \multicolumn{2}{|c|}{8629} & \multicolumn{2}{|c|}{0.04} & \multicolumn{2}{|c|}{0.13} \\
\hline $\mathrm{S}$ at same level of $\mathrm{M}$ & \multicolumn{2}{|c|}{5030} & \multicolumn{2}{|c|}{14947} & \multicolumn{2}{|c|}{5030} & \multicolumn{2}{|c|}{14947} & \multicolumn{2}{|c|}{0.08} & \multicolumn{2}{|c|}{0.23} \\
\hline $\begin{array}{c}\text { M at same or different level } \\
\text { of } S\end{array}$ & \multicolumn{2}{|c|}{4849} & \multicolumn{2}{|c|}{14408} & \multicolumn{2}{|c|}{4849} & \multicolumn{2}{|c|}{14408} & \multicolumn{2}{|c|}{0.13} & \multicolumn{2}{|c|}{0.38} \\
\hline
\end{tabular}

Note: NS - Not significant

Main plots: In-situ moisture conservation practices (M)

$\mathrm{M}_{1}$ : Broad bed and furrows $(\mathrm{BBF})$

$\mathrm{M}_{2}$ : Ridges and furrows $(\mathrm{R} \& \mathrm{~F})$

$\mathrm{M}_{3}$ : Flatbed
Sub plots: Nutrient management $(S)$
$\mathrm{S}_{1}: 60: 30: 30$ NPK kg ha ${ }^{-1}$
$\mathrm{S}_{2}: 90: 45: 45$ NPK kg ha ${ }^{-1}$
$\mathrm{S}_{3}: 60: 30: 30 \mathrm{NPK} \mathrm{kg} \mathrm{ha}^{-1}$ (50\% $\mathrm{N}$ through organic)
$\mathrm{S}_{4}: 90: 45: 45 \mathrm{NPK} \mathrm{kg} \mathrm{ha}^{-1}(50 \% \mathrm{~N}$ through organic) 
The treatment with ridges and furrows along with 90:45:45 NPK kg ha ${ }^{-1}$ (50\% $\mathrm{N}$ through organic) had recorded significantly higher leaf area $\left(77.19 \mathrm{dm}^{2}\right.$ plant $\left.{ }^{-1}\right)$, leaf area index (1.43) and total dry matter production (390.57 g plant $^{-1}$ ) and was found on par with ridges and furrows along with 90:45:45 NPK $\mathrm{kg} \mathrm{ha}^{-1}$ (74.89 $\mathrm{dm}^{2}$ plant $^{-1}, 1.39$ and $383.89 \mathrm{~g} \mathrm{plant}^{-1}$, respectively). Lower leaf area $\left(62.97 \mathrm{dm}^{2}\right.$ plant $\left.^{-1}\right)$, leaf area index (1.17) and total dry matter production (337.38 $\left.\mathrm{g} \mathrm{plant}^{-1}\right)$ was observed in flatbed along with 60:30:30 NPK $\mathrm{kg} \mathrm{ha}{ }^{-1}$. Higher total dry matter production, leaf area and index is due to availability of moisture and nutrients trough out crop period.

Ridges and furrows with application of 90:45:45 NPK kg ha ${ }^{-1}$ (50\% $\mathrm{N}$ through organic) was noticed significantly higher seed cotton yield per hectare (2834 $\left.\mathrm{kg} \mathrm{ha}^{-1}\right)$ and lower seed cotton yield per hectare was recorded in flat bed with application of 60:30:30 NPK kg ha ${ }^{-1}\left(1694 \mathrm{~kg} \mathrm{ha}^{-1}\right)$. Increase in moisture with the former treatments could be ascribed to effectiveness of ridges and furrow system of moisture conservation and applied FYM. Farm yard manure served both as slow releasing nutritional source and as moisture retainer attributed to organic matter directly and indirectly through improvement in soil structure which is so critical in deep black soils. Ridges and furrow reduces the runoff and provide more opportunity time for infiltration. Combination of ridges and furrow along with 90:45:45 NPK kg ha ${ }^{-1}(50 \% \mathrm{~N}$ through organic) was recorded significantly higher gross and net returns ( $\square$ 1,53,018 ha and $\square 1,07,674 \mathrm{ha}^{-1}$, respectively), while lower gross returns was recorded in flatbed with 60:30:30 NPK kg ha ${ }^{-1}$ ( $\square 91478 \mathrm{ha}^{-1}$ and $52556 \mathrm{ha}^{-1}$ ) (Table 3).

Ridges and furrows along with 90:45:45 NPK $\mathrm{kg} \mathrm{ha}{ }^{-1}(50 \% \mathrm{~N}$ through organic) was significantly superior (3.37) over other treatments in benefit cost ratio which was found on par with broad bed and furrows along with 90:45:45 NPK kg ha ${ }^{-1}$ (3.05) and ridges and furrows along with 90:45:45 NPK $\mathrm{kg} \mathrm{ha}{ }^{-1} \mathrm{~kg} \mathrm{ha}^{-1}$ (3.19). Significantly lower (2.23) benefit cost ratio was observed in flatbed along with 90:45:45 NPK $\mathrm{kg} \mathrm{ha}^{-1}$ (50\% $\mathrm{N}$ through organic).

Based on the study, it can be concluded that ridges and furrows, 90:45:45 NPK kg ha (50\% $\mathrm{N}$ through organic) and there interaction effect shows improved growth and yield parameters and also economically feasible over the other treatments.

\section{References}

Anonymous. 2015-16. Annual report. All India Coordinated Research Project on Cotton, India.

Arora, S. and Bhatt, R. 2012. Impact of improved soil and in-situ water conservation practices on productivity in rainfed foothill region of North-west India. http://tucson.ars.ag.gov/isco/isco 15/pdf/Arora\%20S_Impact\%20of\%20i mproved\%20 soil.pdf

Babalad, H. B. and Itnal, C. J. 2004. Integrated nutrient management in cotton and soybean intercropping system under rainfed conditions. International Symposium on Strategies for Sustainable Cotton Production, UAS, Dharwad, India November 23-25. p. 92-97.

Chandrashekara, C. P. and Girijesh, G. K. 2004. Long-term manurial trial on integrated nutrient management for sustainable cotton based cropping system at GLBC area. International Symposium on Strategies for Sustainable Cotton Production, UAS, Dharwad, India 23-25 November 2004. pp. 251-252.

Hosmath, J. A., Biradar, D. P., Deshapande, S. K., Dodamani, S. V., Md. Rizwan 
Haris and Nooli, S. S. 2004. Study of $B t$ and non $B t$ cotton performance in organics and its effect on soil properties and nutrient status. International Symposium on Strategies for Sustainable Cotton Production, UAS, Dharwad, India. 23-25 November. pp. 135-138.

Hulihalli, U. K. and Patil, V. C. 2004. Moisture use efficiency of cotton in relation to in-situ moisture conservation practices and organic manures under rainfed conditions. Indian Journal of Dryland Agricultural Research and Development. 19(2): 154-163.

Maninder, K., Mandeep, K. and Brar, A. S. 2007. Effect of nutrient applied through organics and inorganics sources on the growth and yield of American cotton (Gossypium hirsutum L.). Journal of Cotton Research and Development. 21(2): 194-196.

Narkhede, W. N., Nayak, S. K., Sutar, V. K. and Jaware, B. H. 2015. Effect of land configuration and nutrient management on yield, quality and moisture use efficiency of Bt cotton. Agronomy for Sustainable Development. 3(1):60-63.
Panse, V. G. and Sukhatme, P. V. 1967. Statistical methods for agricultural workers. ICAR publications, New Delhi. p. 359.

Pendke, M. S., Lomte, M. H. and Shinde, J. S. 2001. Impact of land configuration on hydrological properties of soil and yield of cotton. Journal of Maharashtra Agricultural Universities. 26(1): 6-7.

Rannavare, P. K., Nolakhe, S. M. and Solanke, P. S. 2006. Influence of organics, inorganics on production of desi cotton (Gossypium arborium L). Journal of Indian Society of Cotton Improvement. 12: 156-159.

Satyanarayana rao and Setty, R. A. 2007. Nutrients uptake in cotton as influenced by management practices under late sown conditions. Journal of Cotton Research and Development. 21(1):6971.

Sinha, N. P., Prasad, B. and Ghosh, A. B. 1981. Effect of continuous use of fertilizers on yield and nutrient uptake in wheat, soybean and potato cropping system. Journal of Indian Society of Soil Science. 29: 537-542.

\section{How to cite this article:}

Ambika, V., G.S. Yadahalli, B.M. Chittapur, Shamrao Kulkarni, Vidyavathi G. Yadahalli and Siddu Malakannavar. 2017. Influence of Land Configurations and Nutrient Levels on Growth, Yield and Economics of Bt Cotton. Int.J.Curr.Microbiol.App.Sci. 6(12): 3095-3102. doi: https://doi.org/10.20546/ijcmas.2017.612.361 